\title{
GH but not IGF-I or insulin increases lipoprotein lipase activity in muscle tissues of hypophysectomised rats
}

\author{
J Oscarsson, M Ottosson ${ }^{1}$, K Vikman-Adolfsson, F Frick, \\ $\mathbf{S}$ Enerbäck ${ }^{2}, \mathbf{H}$ Lithell $^{3}$ and $\mathbf{S}$ Edén
}

Department of Physiology, Göteborg University, Sweden

${ }^{1}$ The Wallenberg Laboratory, Göteborg, Sweden

${ }^{2}$ The Department of Molecular Biology, Göteborg University, Sweden

${ }^{3}$ Department of Geriatrics, University of Uppsala, Sweden

(Requests for offprints should be addressed to S Edén, Department of Physiology, Göteborg University, Box 434, S-405 30 Göteborg, Sweden)

\begin{abstract}
Changes in GH secretion are associated with changes in serum lipoproteins, utilisation of fuels and body composition. Since lipoprotein lipase (LPL) is a key enzyme in the regulation of lipid and lipoprotein metabolism, changes in LPL activity may contribute to these effects of GH. The present study was undertaken to investigate the role of $\mathrm{GH}$ and the GH-dependent growth factor, IGF-I, in the regulation of LPL in heart, skeletal muscle and adipose tissue. Female rats were hypophysectomised at 50 days of age. One week later, hormonal therapy was commenced. All hypophysectomised rats received L-thyroxine and cortisol. Adipose tissue, the heart, soleus and gastrocnemius muscles were excised after 1 week of hormonal therapy. The effect of insulin injections on adipose tissue and heart LPL activity was also studied. In separate experiments, LPL activity in post-heparin plasma was measured. Hypophysectomy had no effect on adipose tissue LPL activity, whereas activity was reduced in heart, soleus and gastrocnemius muscle tissues. GH treatment had no significant effect on LPL activity in adipose tissue or soleus
\end{abstract}

muscle, but increased the LPL activity in heart and gastrocnemius muscle. GH treatment increased post-heparin plasma LPL activity. Recombinant human IGF-I treatment $(1.25 \mathrm{mg} / \mathrm{kg}$ per day) markedly reduced LPL activity in adipose tissue, but had no effect in muscle tissues. The effect of IGF-I treatment on adipose tissue LPL was not reflected by a decrease in post-heparin plasma LPL activity. Daily injections of insulin for 7 days increased LPL activity in adipose tissue but had no effect on heart LPL activity. In adipose tissue, LPL mRNA levels tended to decrease as a result of IGF-I treatment. In the muscle tissues, no significant effects of hypophysectomy, GH or IGF-I treatment on LPL mRNA levels were observed.

It is concluded that GH increases heart and skeletal muscle tissue LPL activity, which probably contributes to an increased post-heparin plasma LPL activity. The effect of GH on muscle LPL activity is probably not mediated by IGF-I or insulin. Insulin and IGF-I have opposite effects on LPL activity in adipose tissue.

Journal of Endocrinology (1999) 160, 247-255

\section{Introduction}

Lipoprotein lipase (LPL) is a key enzyme in the regulation of the flux of fatty acids. LPL is localised, when active, to the endothelium of the vessel wall, where it hydrolyses triglyceride-rich lipoproteins, e.g. chylomicrons and very low density lipoproteins. Released fatty acids are either re-esterified or metabolised as an energy source. LPL activity is expressed in most tissues of adult animals, except the liver (Cryer 1981, Bensadoun 1991). LPL activity affects levels of circulating lipoproteins, especially serum triglycerides, and is rate limiting for the supply of triglyceride-derived fatty acids to skeletal muscle tissue (Levak-Frank et al. 1995).

The role of growth hormone $(\mathrm{GH})$ in the regulation of LPL activity is not clear. Stimulation and inhibition by GH have been observed, as well as no effects. Post-heparin plasma LPL activity was reduced in acromegaly (Murase et al. 1980) and in GH-treated GH-deficient children (Asayama et al. 1984). However, post-heparin plasma LPL activity was not affected by GH treatment of GHdeficient adults (Oscarsson et al. 1996) or healthy obese men (Oscarsson et al. 1994). In hypophysectomised female rats, post-heparin plasma LPL activity was reduced and GH treatment markedly increased the activity (Vikman-Adolfsson et al. 1994).

Skeletal muscles and adipose tissue are the major tissues expressing LPL activity, and are therefore the main contributors to post-heparin plasma LPL activity (Tan et al. 1977, Cryer 1981, Bensadoun 1991). In adipose tissue, GH has been shown to decrease LPL activity in humans (Ottosson et al. 1995, Oscarsson et al. 1996) and 
rats (Murase et al. 1981, Barber et al. 1992). Comparatively less attention has been paid to the hormonal regulation of muscle LPL activity.

Insulin-like growth factor-I (IGF-I) expression and secretion are mainly regulated by $\mathrm{GH}$ and nutritional factors (Thissen et al. 1994). GH regulates the expression and secretion of IGF-I in many tissues (Humbel 1990), including adipose (Vikman et al. 1991) and muscle tissues (Isgaard et al. 1989). Circulating IGF-I is mainly derived from the liver and is believed to mediate some of the effects of $\mathrm{GH}$ via endocrine mechanisms (Guler et al. 1988, Humbel 1990).

In order to understand further the effects of $\mathrm{GH}$ and the role of IGF-I in the effects of GH on the regulation of LPL, we studied the effects of GH and IGF-I treatment of hypophysectomised rats on LPL activity in adipose and muscle tissues, as well as LPL mRNA expression.

\section{Materials and Methods}

\section{Animals}

Intact and hypophysectomised female Sprague-Dawley rats, 50-65 days old (Møllegaard Breeding Centre Ltd, Ejby, Denmark), were used. They were kept at constant temperature with a $14 \mathrm{~h}: 10 \mathrm{~h}$ light:darkness cycle. Tap water and pelleted food (Type R36, Ewos, Södertälje, Sweden) were freely available. Body weight was measured daily and rats gaining more than $0.5 \mathrm{~g} /$ day in body weight during the observation period of 1 week after hypophysectomy were excluded. The hypophysectomised rats were given hormone therapy for 7 days. In order to determine post-heparin plasma LPL activity, the rats were anaesthetised with a combination of ketamine hydrochloride $(77 \mathrm{mg} / \mathrm{kg}$, Ketalar, Parke-Davis, Detroit, MI, USA) and xylazine ( $9 \mathrm{mg} / \mathrm{kg}$, Rompun, Bayer, Lever-Kusen, Germany). An i.v. injection of heparin (250 IU/kg, Lövens, Ballerup, Denmark) was given into the tail vein. The rats were exsanguinated by open heart puncture $10 \mathrm{~min}$ after the administration of heparin (Krauss et al. 1973, Vikman-Adolfsson et al. 1994). In the other experiments, the rats were killed by decapitation and parametrial and retroperitoneal adipose tissue, heart, soleus and gastrocnemius muscles were taken out, blotted, weighed and stored at $-70{ }^{\circ} \mathrm{C}$ until analysis. If not otherwise stated, the rats were killed between 1000 and $1200 \mathrm{~h}$. The study was approved by the local Ethics Committee.

\section{Hormonal treatment}

L-Thyroxine (Nycomed Ltd, Oslo, Norway; $10 \mu \mathrm{g} / \mathrm{kg}$ per day) and hydrocortisone phosphate (Solu-Cortef, Upjohn, Puurs, Belgium; $400 \mu \mathrm{g} / \mathrm{kg}$ per day) diluted in saline were given as a daily s.c. injection to all the hypophysectomised rats at $0800 \mathrm{~h}$. Recombinant bovine $\mathrm{GH}$ (bGH; potency not specified) was generously provided by American Cyanamid Co. (Princeton, NJ, USA). bGH $(0 \cdot 1,1 \cdot 5$ or $5 \mathrm{mg} / \mathrm{kg}$ per day according to the design of the experiment) was diluted in $0.05 \mathrm{mM}$ phosphate buffer, $\mathrm{pH} 8.6$, with $1.6 \%$ glycerol and $0.02 \%$ sodium azide and given as a continuous infusion via an osmotic mini-pump (Model 2001, Alzet Corporation, Palo Alto, CA, USA) or as two daily injections for 7 days (Oscarsson et al. 1991, VikmanAdolfsson et al. 1994). Human recombinant IGF-I, generously provided by Genentech Inc. (San Francisco, CA, USA), was diluted in saline and infused by osmotic mini-pumps at a dose of $1.25 \mathrm{mg} / \mathrm{kg}$ per day (Sjöberg et al. 1994). Insulin (Insulatard, $100 \mathrm{IU} / \mathrm{ml}$, Novo Nordisk $\mathrm{A} / \mathrm{S}$, Denmark) was diluted in saline and given as a daily s.c. injection at $1600 \mathrm{~h}$. The insulin dose was gradually increased (Gause et al. 1985): day 1-4, 1.0 U/day; day $5-7,2 \cdot 0 \mathrm{U} /$ day. The treatments continued for 7 days.

\section{Serum analysis}

Serum glucose concentrations were measured by the glucose 6-phosphate dehydrogenase method (Merck, Darmstadt, Germany). Serum insulin concentration was determined by a RIA (Phedebas, Pharmacia, Uppsala, Sweden). Serum IGF-I concentrations were determined by a hydrochloride acid-ethanol extraction RIA, using human IGF-I for labelling (Nichols Institute Diagnostics, San Juan Capistrano, CA, USA) (Sjöberg et al. 1994).

\section{$L P L$}

LPL activity in the heart, soleus and gastrocnemius muscle tissues was determined according to Lithell \& Boberg (1978). Briefly, frozen tissue was incubated in a reaction medium at $37^{\circ} \mathrm{C}$. The reaction medium contained $2 \cdot 1 \mathrm{M}$ glycine buffer, $\mathrm{pH} 8 \cdot 4$, and heparin $(240 \mathrm{IU} / \mathrm{ml})$. The triolein emulsion used was according to Nilsson-Ehle \& Schotz (1976). The intra-assay coefficient of variation (CV) calculated from duplicates was $12 \cdot 5 \%$. Activity was expressed as milliunits $(\mathrm{mU})$ per gram tissue ( $1 \mathrm{mU}=1 \mathrm{nmol}$ free fatty acid (FFA) released per minute).

LPL activity was measured in adipose tissue as well as in muscle tissues according to the method of Peterson et al. (1985). In brief, frozen tissue was homogenised in a detergent-containing buffer. To each gram of tissue, $9 \mathrm{ml}$ buffer was added. The homogenate was centrifuged for $5 \mathrm{~min}$ at $15000 \mathrm{~g}$ and the clear solution between the sediment and the floating fat layer was used for the assay of LPL. Muscle and heart tissues were diluted 10 times in buffer before assay. The substrate emulsion used was Intralipid (10\%, Kabi Pharmacia, Stockholm, Sweden) labelled with $\left[{ }^{3} \mathrm{H}\right]$ triolein (Dr Krabisch, Lund University, Lund, Sweden). The samples were incubated in triplicate at $25{ }^{\circ} \mathrm{C}$. Liberated fatty acids were extracted (Spooner et al. 1977) and quantified in a liquid scintillation counter. The intra-assay $\mathrm{CV}$ for determinations in adipose tissue 
Table 1 Effects of recombinant bGH ( $1 \mathrm{mg} / \mathrm{kg}$ per day) or recombinant human IGF-I $(1 \cdot 25 \mathrm{mg} / \mathrm{kg}$ per day) treatment of hypophysectomised $(\mathrm{Hx})$ female rats on body weight gain, adipocyte diameter, serum IGF-1, glucose and insulin. The values are compared with those of normal age-matched females rats (N). Values are means \pm S.E.M. of 10-12 observations, except adipocyte diameter, which was analysed in four rats of each group

\begin{tabular}{|c|c|c|c|c|c|}
\hline & $\begin{array}{l}\text { Weight gain } \\
\text { (g/day) }\end{array}$ & $\begin{array}{l}\text { Adipocyte } \\
\text { diameter }(\mu \mathrm{m})\end{array}$ & $\begin{array}{l}\text { IGF-I } \\
(\mu \mathrm{g} / \mathrm{I})\end{array}$ & $\begin{array}{l}\text { Glucose } \\
(\mathrm{mmol} / \mathrm{l})\end{array}$ & $\begin{array}{l}\text { Insulin } \\
(\mathrm{mU} / \mathrm{l})\end{array}$ \\
\hline \multicolumn{6}{|l|}{ Group } \\
\hline $\mathrm{N}$ & $2 \cdot 5 \pm 0 \cdot 1^{a}$ & $66 \cdot 3 \pm 1 \cdot 8$ & $1148 \pm 68^{a}$ & $7 \cdot 4 \pm 0 \cdot 3$ & $11 \cdot 5 \pm 0 \cdot 8^{a}$ \\
\hline $\mathrm{Hx}$ & $-0 \cdot 7 \pm 0.3^{b}$ & $54 \cdot 2 \pm 5 \cdot 0$ & $183 \pm 33^{b}$ & $7 \cdot 1 \pm 0 \cdot 2$ & $7 \cdot 5 \pm 0 \cdot 2^{b}$ \\
\hline $\mathrm{Hx}+\mathrm{GH}$ & $3 \cdot 4 \pm 0 \cdot 3^{\mathrm{c}}$ & $57 \cdot 3 \pm 1 \cdot 6$ & $712 \pm 48^{\mathrm{c}}$ & $7 \cdot 4 \pm 0 \cdot 3$ & $10 \cdot 3 \pm 0 \cdot 9^{a}$ \\
\hline $\mathrm{Hx}+\mathrm{IGF}-\mathrm{I}$ & $1 \cdot 8 \pm 0 \cdot 2^{\mathrm{d}}$ & $58 \cdot 1 \pm 1 \cdot 5$ & $302 \pm 60^{d}$ & $7 \cdot 7 \pm 0 \cdot 2$ & $6 \cdot 5 \pm 0 \cdot 4^{b}$ \\
\hline
\end{tabular}

Rats were hypophysectomised at 50 days of age. After 1 week of observation, the rats were given hormones for 7 days. All hypophysectomised rats were given L-thyroxine $(10 \mu \mathrm{g} / \mathrm{kg}$ per day) and cortisol phosphate $(400 \mu \mathrm{g} / \mathrm{kg}$ per day). GH and IGF-I were given as a continuous infusion by means of osmotic mini-pumps. IGF-I, insulin, glucose concentrations and adipocyte diameter in parametrial fat were analysed as described in Materials and Methods.

In all columns, values with different superscripts are significantly different from each other ( $P<0 \cdot 05$, ANOVA followed by Student-Newman-Keul's test).

was $6 \%$, and in heart and gastrocnemius muscle tissues, $5 \%$. Activity was expressed as $\mathrm{mU}$ per gram tissue (1 mU=1 nmol FFA released per minute).

The diameter of adipocytes in parametrial fat was determined as previously described (Smith et al. 1972). Each observation is the mean of 100 cell diameters.

Post-heparin plasma LPL activity was determined according to Nilsson-Ehle \& Ekman (1977), as previously described (Vikman-Adolfsson et al. 1994). The activity was expressed as micromoles fatty acids released per minute per millilitre plasma. The intra-assay CV was $6 \%$. All samples were run in one single assay.

\section{LPL probe}

$\left[{ }^{32} \mathrm{P}\right]$ UTP- or $\left[{ }^{35} \mathrm{~S}\right]$ UTP-labelled antisense LPL RNA was synthesised using an EcoR1 linearised plasmid pGem 4Z (Samuelsson et al. 1991) as template. The plasmid contains a $550 \mathrm{bp}$ fragment of guinea pig cDNA which has $82 \%$ homology with rat cDNA (Enerbäck et al. 1987, Brault et al. 1992). This probe was found to give a single transcript of $3.6 \mathrm{~kb}$ using Northern blot (data not shown), which is the expected size of LPL mRNA in the rat (Brault et al. 1992). Sense LPL RNA was synthesised using an SST linearised plasmid.

\section{RNase protection solution hybridisation assay}

Total nucleic acids (TNA) were prepared according to the method of Durnam \& Palmiter (1983). In brief, the tissue was homogenised in a buffer containing 1\% SDS, $20 \mathrm{mM}$ Tris- $\mathrm{HCl}(\mathrm{pH} 7 \cdot 5)$ and $4 \mathrm{mM}$ EDTA and digested with proteinase-K $(20 \mu \mathrm{g} / \mathrm{ml})$ overnight. TNA were then extracted with phenol-chloroform. The hybridisation was performed with TNA samples at $70{ }^{\circ} \mathrm{C}$ for $24 \mathrm{~h}$ in $0.6 \mathrm{M}$ $\mathrm{NaCl}, 20 \mathrm{mM}$ Tris-HCl (pH 7.5), 4 mM EDTA, 0.1\% SDS, $0.75 \mathrm{mM}$ dithiothreitol, $3.3 \mu \mathrm{g}$ tRNA, $25 \%$ formamide with a $\left[{ }^{35} \mathrm{~S}\right] \mathrm{UTP}-$ labelled LPL cRNA probe in a volume of $40 \mu \mathrm{l}$. The samples were then treated with
$40 \mu \mathrm{g}$ RNase A and $2 \mu \mathrm{g}$ RNase $\mathrm{T}_{1}$ in the presence of $100 \mu \mathrm{g}$ herring sperm DNA for $45 \mathrm{~min}$ at $37^{\circ} \mathrm{C}$ in a volume of $1 \mathrm{ml}$. Protected probe was precipitated with $100 \mu \mathrm{l}$ trichloroacetic acid $(6 \mathrm{M})$. The precipitate was collected on glass-fibre filters (GF/C, Whatman International Ltd, Maidstone, UK) and radioactivity counted in a liquid scintillation counter. The signal was compared with a standard curve which was obtained by hybridisation of in vitro-transcribed LPL mRNA (Samuelsson et al. 1991). The DNA content in the samples was analysed according to Labarca \& Paigen (1980) and 3-20 $\mu$ g DNA were assayed. Within this range, the hybridisation signal paralleled the standard curve. The intra-assay CV calculated from duplicates was $6 \%$. The results are expressed as amount of LPL mRNA/DNA (amol/ $\mu \mathrm{g})$.

\section{Statistics}

Values are given as means \pm s.E.M. Comparisons between groups were performed with ANOVA followed by Student-Newman-Keul's multiple range test. $P$ values less than 0.05 were considered significant. Values were transformed to logarithms when appropriate.

\section{Results}

GH and IGF-I treatment of hypophysectomised rats resulted in a significant increase in body weight. Serum IGF-I concentrations were increased by both treatments. However, IGF-I treatment resulted in lower serum IGF-I levels and body weight gain than GH treatment (Table 1). $\mathrm{GH}$ treatment resulted in higher serum insulin concentrations compared with hypophysectomised rats, whereas IGF-I treatment had no effect on the insulin concentrations. Neither GH nor IGF-I treatment had any effect on serum glucose concentrations (Table 1). After 2 days of treatment, serum insulin was already increased by $\mathrm{GH}$ treatment, but IGF-I treatment had no effect (data not 
shown). LPL activity was determined in heart and predominantly white (gastrocnemius) and red (soleus) skeletal muscle by the method of Lithell \& Boberg (1978). In heart, gastrocnemius muscle and soleus muscle, LPL activity was reduced in the hypophysectomised rats given thyroxine and cortisol substitution (Fig. 1). GH treatment increased LPL activity in heart (20\%) and gastrocnemius muscle (50\%). The LPL activity in the gastrocnemius muscle was lower compared with heart and soleus muscle. In soleus muscle, there was no significant effect of $\mathrm{GH}$ treatment, although the activity tended to be higher also in this muscle after GH treatment. IGF-I treatment had no effect on LPL activity in the muscle tissues (Fig. 1). LPL activity in the parametrial adipose tissue was measured by the method of Peterson et al. (1985). LPL activity in adipose tissue was not affected by hypophysectomy or GH treatment. In contrast, IGF-I treatment markedly reduced LPL activity in the parametrial adipose tissue (Fig. 1). The diameter of adipocytes isolated from parametrial adipose tissue was not affected by the hormonal treatment (Table 1), indicating that the LPL activity per cell was affected.

In order to determine if there was any effect of the hormones on LPL mRNA levels, LPL mRNA was quantified with an RNase protection solution hybridisation assay (Table 2). In adipose tissue from IGF-I-treated animals, LPL mRNA levels were reduced compared with those in adipose tissue from normal and $\mathrm{GH}$-treated hypophysectomised rats, but there was no effect of any of the treatments on LPL mRNA levels in heart or gastrocnemius muscle.

The lack of effect of GH treatment on LPL activity in parametrial adipose tissue was surprising in view of previous findings in the rat on this activity (Murase et al. 1981, Barber et al. 1992). Although the experimental designs differ in several ways, one obvious difference is the mode of administration of GH. It is possible that two daily injections, as previously used by Barber et al. (1992), could result in another response, which could be dependent on the time of killing. Hypophysectomised rats were therefore given two daily injections or a continuous infusion of $\mathrm{GH}$ for 7 days. The rats were killed as indicated in Table 3 . There was no effect of either two daily injections or a continuous infusion of $\mathrm{GH}$ on the parametrial adipose tissue LPL activity compared with control (one-way ANOVA). However, at all time-points LPL activity tended to be more stimulated when the rats were given a continuous infusion of GH (Table 3). When the two modes of administration were compared (two-way ANOVA), it was revealed that a continuous infusion resulted in a higher LPL activity than two daily injections, and that the time of killing had no impact on LPL activity.

LPL activity in heart and skeletal muscle was also analysed in tissue homogenate using the method of Peterson et al. (1985). Heart LPL activity in hypophysectomised rats was $54 \pm 7 \%(n=7)$ of that in normal rats $(100 \pm 3 \%, n=6)(P<0 \cdot 05)$. This method also detected a significant reduction $(P<0 \cdot 05)$ in LPL activity in gastrocnemius muscle following hypophysectomy $(74 \pm 5 \%, n=7)$ compared with normal rats $(100 \pm 6 \%, n=6)$. Thus, the methods used gave similar results regarding the effect of hypophysectomy on LPL activity in heart and the gastrocnemius muscle. The effect of different doses of GH in hypophysectomised rats on LPL activity in heart and the gastrocnemius muscle was then determined (Table 4). The highest dose of $\mathrm{GH}$ used $(5 \mathrm{mg} / \mathrm{kg})$ resulted in a $26 \%$ increase in heart LPL activity and a $35 \%$ increase in gastrocnemius muscle LPL activity (Table 4).

GH treatment increased serum insulin concentrations (Table 1). In order to investigate if the effect of $\mathrm{GH}$ on LPL activities was indirect via the effect on insulin, daily injections of insulin were given to hypophysectomised rats for 7 days. The effect of insulin was compared with that of a continuous infusion of GH (Fig. 2). Insulin treatment had no effect on heart LPL activity, in contrast to GH. In adipose tissue, insulin treatment increased LPL activity by nearly $80 \%$, whereas $\mathrm{GH}$ had no significant effect (cf. Table 3). Serum insulin concentrations were increased 2to 3-fold by the insulin treatment (data not shown), in line with previous results (Gause et al. 1985).

Finally, the effect of IGF-I and GH on post-heparin plasma LPL activity was investigated. IGF-I treatment had no effect on heparin-releasable LPL activity (Table 5). However, post-heparin LPL activity was reduced after hypophysectomy and increased after GH treatment.

\section{Discussion}

In the present study, we show for the first time that $\mathrm{GH}$ increases LPL activity in skeletal muscles and heart. The most prominent effect of $\mathrm{GH}$ was observed in predominantly white skeletal muscle (gastrocnemius). The effects of GH did not seem to be mediated via IGF-I, since IGF-I in contrast to GH had no effect on LPL activity in heart or skeletal muscles. Moreover, the effect of GH on muscle LPL activity was probably not mediated by insulin, since insulin treatment, in contrast to $\mathrm{GH}$ treatment, had no effect on heart LPL activity. IGF-I treatment and insulin treatment had opposite effects on adipose tissue LPL activity. Although GH enhances the production and secretion of IGF-I in the adipose tissue of the rat (Vikman et al. 1991), GH treatment had no effect on LPL activity in adipose tissue. It is therefore possible that $\mathrm{GH}$, via mechanisms not involving IGF-I production, has an effect opposite to that of IGF-I on LPL activity. We did not observe any significant effect of GH or IGF-I on LPL mRNA levels in adipose tissue, although IGF-I treatment tended to decrease LPL mRNA levels. Other studies in the rat have indicated that GH decreases LPL activity in adipose tissue (Murase et al. 1981, Barber et al. 1992). The discrepant results may be explained by different 
experimental designs and differences in the duration of treatment. For example, the higher LPL activity in parametrial adipose tissue following a continuous infusion of
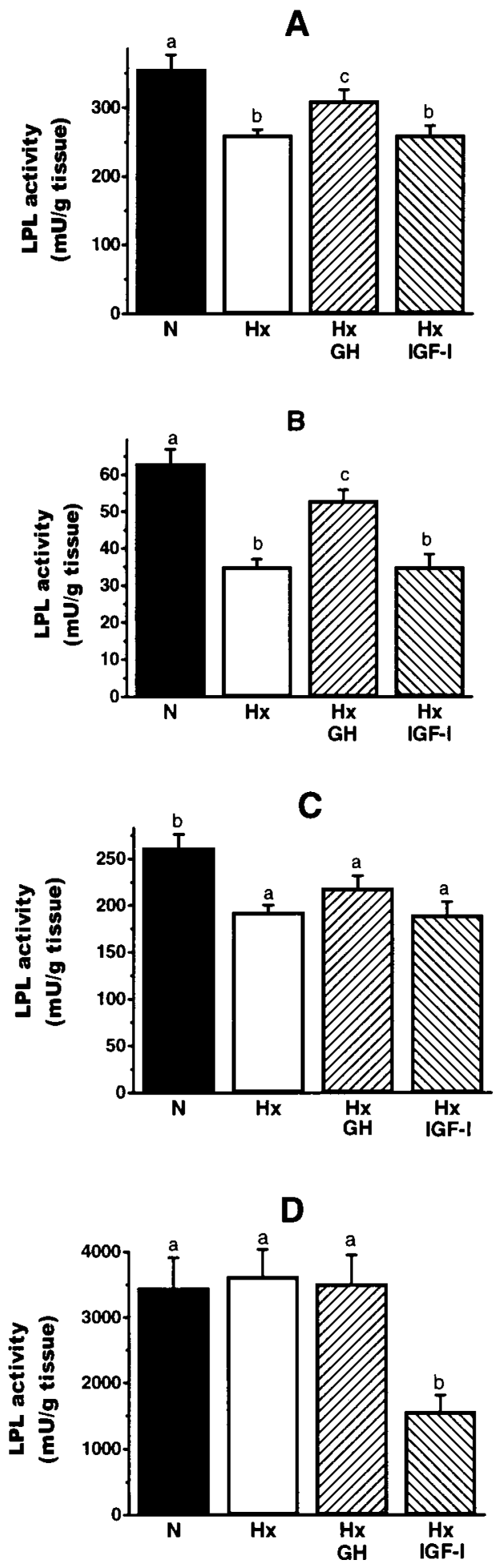

Table 2 Effects of recombinant bGH ( $1 \mathrm{mg} / \mathrm{kg}$ per day) or recombinant human IGF-I $(1.25 \mathrm{mg} / \mathrm{kg}$ per day) treatment of hypophysectomised $(\mathrm{Hx})$ female rats on LPL mRNA levels in heart, gastrocnemius muscle and parametrial adipose tissue. The values are compared with those of normal age-matched female rats $(\mathrm{N})$. Values are means \pm S.E.M. of 10-12 observations

LPL mRNA (amol/ $\mu \mathrm{g}$ DNA)

\begin{tabular}{|c|c|c|c|}
\hline \multirow[b]{2}{*}{ Group } & Heart & Gastrocnemius & Adipose tissue \\
\hline & & & \\
\hline $\mathrm{N}$ & $55 \pm 10$ & $14 \pm 1$ & $108 \pm 9^{a}$ \\
\hline $\mathrm{Hx}$ & $45 \pm 3$ & $17 \pm 2$ & $90 \pm 9^{a b}$ \\
\hline $\mathrm{Hx}+\mathrm{GH}$ & $56 \pm 5$ & $14 \pm 1$ & $108 \pm 5^{\mathrm{a}}$ \\
\hline $\mathrm{Hx}+\mathrm{IGF}-\mathrm{I}$ & $50 \pm 6$ & $14 \pm 2$ & $73 \pm 10^{b}$ \\
\hline
\end{tabular}

Rats were hypophysectomised at 50 days of age. After 1 week of observation, the rats were given hormones for 7 days. All hypophysectomised rats were given L-thyroxine $(10 \mu \mathrm{g} / \mathrm{kg}$ per day) and cortisol phosphate $(400 \mu \mathrm{g} / \mathrm{kg}$ per day). LPL mRNA levels were analysed as described in Materials and Methods.

In all columns, values with different superscripts are significantly different from each other $(P<0 \cdot 05$, ANOVA followed by Student-Newman-Keul's test).

$\mathrm{GH}$ indicates that the mode of $\mathrm{GH}$ administration could be of importance.

Although IGF-I markedly decreased LPL activity in adipose tissue, IGF-I treatment did not affect heparinreleasable LPL activity. However, the increased LPL activity in muscle tissues after GH treatment may explain the increased post-heparin plasma LPL activity as found previously (Vikman-Adolfsson et al. 1994) because of the much larger proportion of muscle tissue compared with adipose tissue in the rat (Roberts et al. 1992).

In line with previous studies, the highest LPL activity was measured in heart and adipose tissue, followed by red skeletal muscle (soleus), and the lowest activity in predominantly white skeletal muscle (gastrocnemius) (Linder et al. 1976, Tan et al. 1977). Similar differences between the tissues were also noticed on the LPL mRNA levels. Two different methods were used to measure muscle LPL activity. The effects of hypophysectomy and hormones were similar using these methods, indicating that the

Figure 1 Effect of $\mathrm{GH}(1 \mathrm{mg} / \mathrm{kg}$ per day) or IGF-I $(1.25 \mathrm{mg} / \mathrm{kg}$ per day) treatment of hypophysectomised $(\mathrm{Hx})$ rats on $\mathrm{LPL}$ activity in the heart $(A)$, gastrocnemius muscle $(B)$, soleus muscle $(C)$ and parametrial adipose tissue (D). Rats were hypophysectomised at 50 days of age. After 1 week of observation the rats were given hormones for 7 days. All hypophysectomised rats were given L-thyroxine ( $10 \mu \mathrm{g} / \mathrm{kg}$ per day) and cortisol phosphate $(400 \mu \mathrm{g} / \mathrm{kg}$ per day). LPL activity in heart and skeletal muscle tissues was analysed according to the method of Lithell \& Boberg (1978) and LPL activity in adipose tissue analysed according to the method of Peterson et al. (1985). The values are compared with those of normal age-matched female rats $(\mathrm{N})$. Values are means \pm S.E.M. of eight observations in each group. Values with different superscripts are significantly different from each other $(P<0 \cdot 05$, ANOVA followed by Student-Newman-Keul's test). 
Table 3 Effects of two daily injections and continuous infusion of recombinant bGH ( $1 \mathrm{mg} / \mathrm{kg}$ per day) on LPL activity in parametrial adipose tissue at different time points during the day. Values are means \pm S.E.M. of six observations in each group

\begin{tabular}{|c|c|c|}
\hline & Hormonal treatment & $\begin{array}{l}\text { LPL activity } \\
\text { (mU/g tissue) }\end{array}$ \\
\hline \multicolumn{3}{|l|}{ Time of killing } \\
\hline \multirow{3}{*}{$1100-1200 \mathrm{~h}$} & Controls & $3362 \pm 260$ \\
\hline & $\mathrm{GH} \times 2$ & $3273 \pm 127$ \\
\hline & $\mathrm{GH}$ continuous & $4684 \pm 670$ \\
\hline \multirow[t]{2}{*}{$1600-1700 \mathrm{~h}$} & $\mathrm{GH} \times 2$ & $4086 \pm 389$ \\
\hline & GH continuous & $4234 \pm 526$ \\
\hline \multirow[t]{2}{*}{ 1900-2000 h } & $\mathrm{GH} \times 2$ & $3487 \pm 246$ \\
\hline & $\mathrm{GH}$ continuous & $4801 \pm 524$ \\
\hline
\end{tabular}

Female rats were hypophysectomised at 50 days of age. After 1 week of observation, the rats were given hormones for 7 days. All rats, including controls, were hypophysectomised and given L-thyroxine $(10 \mu \mathrm{g} / \mathrm{kg}$ per day $)$ and cortisol phosphate $(400 \mu \mathrm{g} / \mathrm{kg}$ per day). LPL activity in parametrial adipose tissue was analysed according to the method of Peterson et al. (1985).

Values were analysed with one-way and two-way tANOVA followed by Student-Newman-Keul's test.

Table 4 Effects of different doses of recombinant bGH in hypophysectomised female rats on LPL activity in the heart and gastrocnemius muscle tissues. Values are means \pm S.E.M. of eight observations in each group

\section{LPL activity (mU/g tissues)}

\begin{tabular}{|c|c|c|}
\hline & Heart & Gastrocnemius muscle \\
\hline \multicolumn{3}{|c|}{ Treatment (mg bGH/kg per day) } \\
\hline Control & $2995 \pm 49^{b}$ & $265 \pm 25^{b}$ \\
\hline $0 \cdot 1$ & $2919 \pm 72^{b}$ & $317 \pm 28^{\mathrm{ab}}$ \\
\hline 1 & $3309 \pm 168^{\mathrm{ab}}$ & $382 \pm 28^{\mathrm{a}}$ \\
\hline 5 & $3722 \pm 279^{a}$ & $358 \pm 19^{a}$ \\
\hline
\end{tabular}

Rats were hypophysectomised at 50 days of age. After 1 week of observation, the rats were given hormones for 7 days. All rats, including controls, were hypophysectomised and given L-thyroxine $(10 \mu \mathrm{g} / \mathrm{kg}$ per day) and cortisol phosphate ( $400 \mu \mathrm{g} / \mathrm{kg}$ per day). LPL activity in heart and gastrocnemius muscle was analysed according to the method of Peterson et al. (1985).

Values with different superscripts are significantly different from each other $(P<0 \cdot 05$, ANOVA followed by Student-Newman-Keul's test).

heparin-extracted activity (Lithell \& Boberg 1978) mirrors the total LPL activity in a tissue homogenate (Peterson et al. 1985) in these experimental situations.

Apart from the hormonal changes induced by hypophysectomy in the present model, other non-hormonal factors such as food intake may influence the measured LPL activity (Cryer 1981). However, food intake has been shown to be unaffected by GH (Clark et al. 1985, Roberts et al. 1992) and IGF-I treatment of rats (Sjöberg et al. 1994). Hypophysectomised rats were given replacement therapy with L-thyroxine and cortisol in doses previously shown to be within the physiological range (Thorngren \& Hansson 1973, Jansson et al. 1982). The dose of GH given
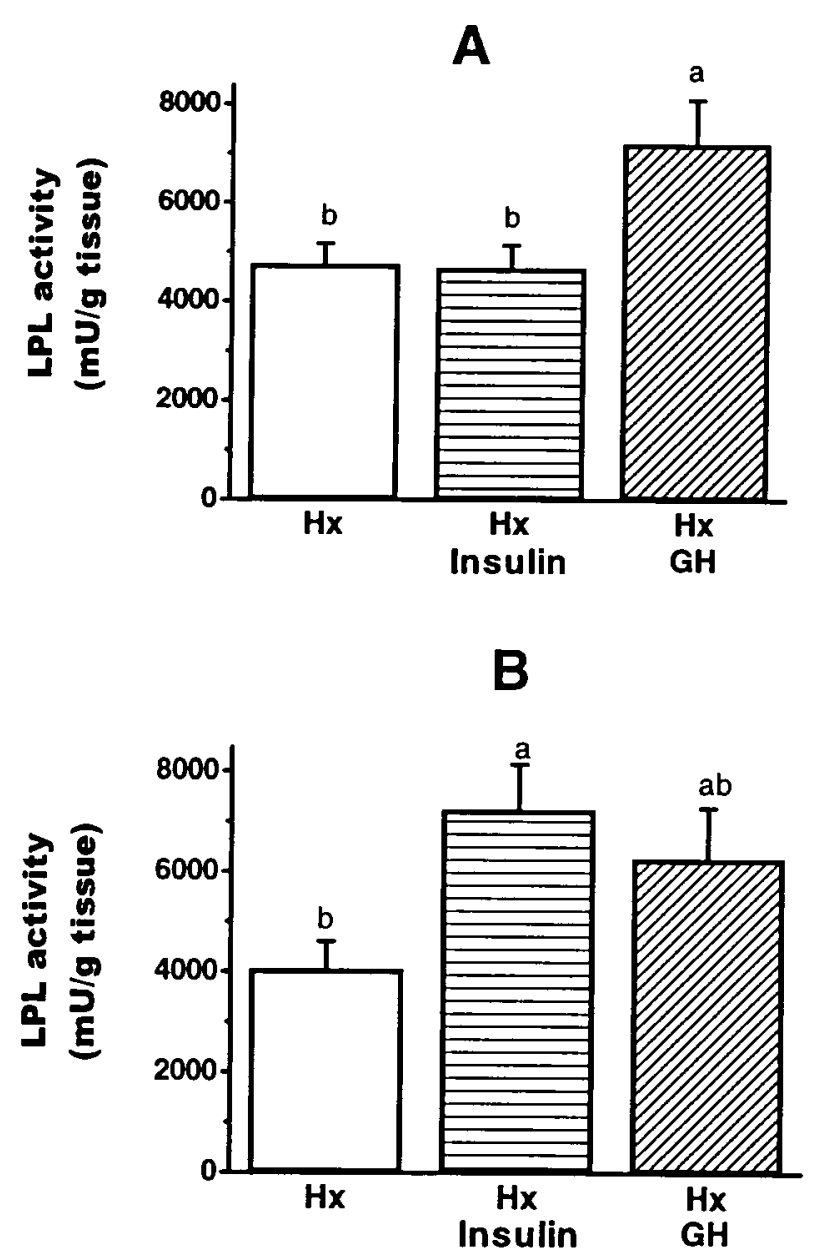

Figure 2 Effect of $\mathrm{GH}$ and insulin treatment of hypophysectomised $(\mathrm{Hx})$ rats on LPL activity in the heart $(\mathrm{A})$ and parametrial adipose tissue (B). Rats were hypophysectomised at 50 days of age. After 7-10 days of observation the rats were hormonally treated for 7 days. All hypophysectomised rats were given L-thyroxine $(10 \mu \mathrm{g} / \mathrm{kg}$ per day) and cortisol phosphate $(400 \mu \mathrm{g} / \mathrm{kg}$ per day) as a daily s.c. injection. bGH $(1.5 \mathrm{mg} / \mathrm{kg}$ per day) was given as a continuous infusion by means of osmotic mini-pumps. Insulin was given as a daily s.c. injection at $1600 \mathrm{~h}$. The dose was gradually increased: days 1 to $4,1.0 \mathrm{U} /$ day; days 5 to $7,2.0 \mathrm{U} /$ day. LPL activity in heart and parametrial adipose tissue was analysed according to the method of Peterson et al. (1985). There were four or five rats in each group. Values are means \pm S.E.M. Values with different superscripts are significantly different from each other $(P<0 \cdot 05$, ANOVA followed by Student-Newman-Keul's test).

in these experiments ( 1 or $1.5 \mathrm{mg} / \mathrm{kg}$ per day) is considered to be within the physiological range. This assumption is based on the knowledge of the integrated serum concentration of GH in 50- to 60-day-old female rats (Jansson et al. 1985) and the plasma clearance rate of GH (Frohman \& Bernardis 1970). Human IGF-I with 3 of 70 amino acids different from rat IGF-I is more potent in vitro than rat IGF-I on rat adipocytes (Tamura et al. 1989). The dose used in our experiments increased body weight to the 
Table 5 Effects of recombinant bGH ( $1 \mathrm{mg} / \mathrm{kg}$ per day) or recombinant human IGF-I $(1.25 \mathrm{mg} / \mathrm{kg}$ per day) treatment of hypophysectomised $(\mathrm{Hx})$ female rats on post-heparin plasma LPL activity. Values are means \pm S.E.M. of five observations in each group

\begin{tabular}{|c|c|c|}
\hline & Hormone & $\begin{array}{l}\text { Post-heparin LPL activity } \\
(\mu \mathrm{mol} / \mathrm{min} \text { per } \mathrm{ml})\end{array}$ \\
\hline \multicolumn{3}{|l|}{$\begin{array}{l}\text { Group of } \\
\text { animals }\end{array}$} \\
\hline $\mathrm{N}$ & - & $0 \cdot 90 \pm 0.02^{\mathrm{a}}$ \\
\hline $\mathrm{Hx}$ & - & $0.64 \pm 0.03^{b}$ \\
\hline $\mathrm{Hx}$ & IGF-I & $0.74 \pm 0.03^{b}$ \\
\hline $\mathrm{Hx}$ & $\mathrm{GH}$ & $1 \cdot 11 \pm 0.02^{c}$ \\
\hline
\end{tabular}

Rats were hypophysectomised at 50 days of age. After 1 week of observation, the rats were given hormones for 7 days. All hypophysectomised rats were given L-thyroxine $(10 \mu \mathrm{g} / \mathrm{kg}$ per day) and cortisol phosphate $(400 \mu \mathrm{g} / \mathrm{kg}$ per day). Post-heparin plasma LPL activity was analysed as described in Materials and Methods. The values are compared with those of normal age-matched female rats $(\mathrm{N})$.

Values with different superscripts are significantly different from each other $(P<0 \cdot 05$, ANOVA followed by Student-Newman-Keul's test).

same extent as in previous reports (Guler et al. 1988) and has been shown to result in nearly normalised serum concentrations of IGF-I (Sjöberg et al. 1994). Glucose concentrations were not altered by IGF-I treatment, indicating that the continuous infusion of IGF-I did not induce hypoglycaemia. IGF-I has been reported to acutely inhibit insulin secretion (Leahy \& Vandekerkhove 1990). In contrast, longer exposure of rat islets to IGF-I increased insulin secretion (Sieradzki et al. 1988). In these and previous experiments (Sjöberg et al. 1994), we have not been able to detect any effects of IGF-I treatment on serum insulin concentrations. We therefore consider it unlikely that any change in insulin secretion would have influenced the effect of IGF-I treatment on LPL activity. However, it cannot be excluded that 7 days of IGF-I treatment decreased the insulin responsiveness of adipose tissue.

Hypophysectomy and $\mathrm{GH}$ treatment changed serum concentrations of insulin, indicating that the effects of $\mathrm{GH}$ could be due to alterations in insulin levels. A stimulatory effect of insulin on LPL activity in adipose tissue due to transcriptional as well as translational and post-translational effects has been described (Eckel et al. 1984, Ong et al. 1988). In line with these observations, an increase in adipose tissue LPL activity occurred after insulin treatment of hypophysectomised rats.

In heart and skeletal muscle tissues, insulin has been shown to have a less pronounced effect than in adipose tissue on LPL activity (Deshaise et al. 1990). Moreover, fasting/feeding seems to have a less pronounced and less consistent effect on LPL activity in muscle tissues than in adipose tissue, in most studies reflected in no change or increased muscle LPL activity during fasting (Linder et al. 1976, Tan et al. 1977, Ladu et al. 1991). In line with these results, there was no effect of insulin treatment on heart
LPL activity, but a marked effect on adipose tissue LPL activity. GH treatment has been shown to decrease basal and insulin-stimulated glucose uptake in muscles of the rat (Goodman \& Schwartz 1974, Davidson 1979), indicating decreased insulin responsiveness. Serum insulin levels were increased by GH treatment without any effect on glucose concentrations, indicating that decreased insulin responsiveness was balanced by an increased insulin secretion. Thus, it is unlikely that changes in insulin secretion and insulin responsiveness could explain the effect of $\mathrm{GH}$ on muscle tissue LPL activity.

$\mathrm{GH}$ has lipolytic and anti-lipogenic effects in adipose tissue, which may result in increased availability of fatty acids in other tissues. It has been proposed that this effect of $\mathrm{GH}$ results in a decreased respiratory ratio and a decreased use of glucose as a fuel, especially in muscle tissues (Randle et al. 1963, Goodman \& Schwartz 1974). An increase in LPL activity in heart and skeletal muscle as a result of $\mathrm{GH}$ action could further increase the availability of fatty acids in these tissues, since LPL activity in skeletal muscle has been shown to be rate limiting for the uptake of triglyceride-derived fatty acids in this tissue (LevakFrank et al. 1995). The effect of GH on LPL activity in muscle tissue indicates that the increased use of fatty acids in muscle tissue as a result of $\mathrm{GH}$ action is not only a result of increased availability of circulating fatty acids. Moreover, changes in insulin responsiveness in muscle tissues following $\mathrm{GH}$ treatment may in part be explained by the effects of GH on LPL activity in these tissues.

Although GH increases the production and secretion of IGF-I from various tissues, the effects of these hormones differ in several aspects, especially regarding effects on lipid and lipoprotein metabolism. GH treatment of hypophysectomised rats reduced serum concentrations of apolipoprotein B and decreased triglyceride concentrations (Oscarsson et al. 1991), whereas IGF-I treatment increased apolipoprotein B and triglyceride concentrations (Sjöberg et al. 1994). These findings are in line with observations made in GH and IGF-I transgenic mice, in which serum triglyceride levels were increased in IGF-I transgenic mice but not in GH transgenic mice (Quaife et al. 1989). The different effects of GH and IGF-I are further substantiated by the present finding of different effects of these hormones on LPL activity. Thus, several effects of GH on lipid and lipoprotein metabolism may actually be balanced by opposing effects of IGF-I.

There are few studies on the effect of IGF-I on LPL activity. In mature 3T3-L1 adipocytes (Spooner et al. 1979), as well as in human isolated adipocytes (Kern et al. 1988), IGF-I increased LPL activity. The discrepancy between these two studies and our results in adipose tissue could be due to different effects of IGF-I in an acute experiment compared with effects of long-term treatment with IGF-I. The different results could also be due to species differences. Such a difference may be at the level of receptors, since rat adipocytes seem to lack IGF-I receptors 
(King \& Kahn 1980). Thus, the mechanism for the inhibitory effect of IGF-I on LPL activity in adipose tissue is not clear, but may involve effects of IGF-I on other cells in the vicinity of the adipocytes. In view of the present results and previous reports, it seems appropriate to conclude that IGF-I plays an important role in the regulation of intermediary metabolism, serving as a modulator of the effects of $\mathrm{GH}$ and probably also insulin in this regulation.

In the rat, GH treatment has been shown to increase carcass protein without affecting carcass fat or parametrial fat pad weight (Roberts et al. 1992). However, IGF-I treatment of hypophysectomised rats (Guler et al. 1988) and diabetic rats (Tomas et al. 1993) resulted in reduced weight of the epididymal fat pad and decreased carcass fat. Thus, the effects of GH and IGF-I on LPL activity may play a role in metabolic adjustments, resulting in changed utilisation of fuels and body composition.

\section{Acknowledgements}

We are grateful to Barbro Basta, Ann-Sofie Lidmer, Birgitta Odén, Carolina Simonsson and Siv Tengblad for excellent technical assistance. This study was supported by the Swedish Medical Research Council (Grant 8269 and 04P-11010), the Nordisk Insulin Foundation, Göteborg Medical Society, Åke Wibergs Foundation, Tore Nilson Foundation, Magnus Bergvalls Foundation, Handlaren Hjalmar Svensson Foundation and The Swedish Medical Society.

\section{References}

Asayama K, Amemiya S, Kusano S \& Kato K 1984 Growthhormone-induced changes in postheparin plasma lipoprotein lipase and hepatic triglyceride lipase activities. Metabolism 33 129-131.

Barber MC, Clegg RA, Finley E, Vernon RG \& Flint DJ 1992 The role of growth hormone, prolactin and insulin-like growth factors in the regulation of rat mammary gland and adipose tissue metabolism during lactation. Journal of Endocrinology 135 195-202.

Bensadoun A 1991 Lipoprotein lipase. Annual Review of Nutrition 11 217-237.

Brault D, Noé L, Etienne J, Hamelin J, Raisonnier A, Souli A, Chuat J-C, Dugail I, Quignard-Boulangé A, Lavau M \& Galibert F 1992 Sequence of rat lipoprotein lipase-encoding cDNA. Gene 121 237-246.

Clark RG, Jansson J-O, Isaksson O \& Robinson ICAF 1985 Intravenous growth hormone: growth responses to patterned infusions in hypophysectomized rats. Journal of Endocrinology 104 53-61.

Cryer A 1981 Tissue lipoprotein lipase activity and its action in lipoprotein metabolism. International Journal of Biochemistry 13 525-541.

Davidson MB 1979 Effect of growth hormone administration to hypophysectomized rats on muscle lipid metabolism. Metabolism 28 729-734.

Deshaise Y, Géloën A, Paulin A \& Bukowiecki LJ 1990 Restoration of lipoprotein lipase activity in insulin-deficient rats by insulin infusion is tissue-specific. Canadian Journal of Physiology and Pharmacology 69 746-751.
Durnam D \& Palmiter RD 1983 A practical approach for quantitating specific mRNAs by solution hybridization. Annals of Biochemistry 131 385-393.

Eckel RH, Prasad JE, Kern PA \& Marshall S 1984 Insulin regulation of lipoprotein lipase in cultured isolated rat adipocytes. Endocrinology 114 1665-1671.

Enerbäck S, Semb H, Bengtsson-Olivercrona G, Carlsson P, Hermansson M-L, Olivercrona T \& Bjursell G 1987 Molecular cloning and sequence analysis of cDNA encoding lipoprotein lipase of guinea pig. Gene 58 1-12.

Frohman LA \& Bernardis LL 1970 Growth hormone secretion in the rat: metabolic clearance and secretion rates. Endocrinology $\mathbf{8 6}$ $305-312$

Gause I, Isaksson O, Lindahl A \& Edén S 1985 Effect of insulin treatment of hypophysectomized rats on adipose tissue responsiveness to insulin and growth hormone. Endocrinology 116 945-951.

Goodman H \& Schwartz J 1974 Growth hormone and lipid metabolism. In Handbook in Physiology, vol 4, pp 211-232. Eds E Knobil \& WH Sawyer. Washington DC: American Physiological Society.

Guler H-P, Zapf J, Schweiwiller E \& Froesch ER 1988 Recombinant human insulin-like growth factor I stimulates growth and has distinct effects on organ size in hypophysectomized rats. Proceedings of the National Academy of Sciences of the USA 85 4889-4893.

Humbel RE 1990 Insulin-like growth factor I and II. European Journal of Biochemistry 190 445-462.

Isgaard J, Nilsson A, Vikman K \& Isaksson OGP 1989 Growth hormone regulates the level of insulin-like growth factor-I mRNA in rat skeletal muscle. Journal of Endocrinology 120 107-112.

Jansson J-O, Albertsson-Wikland K, Edén S, Thorngren KG \& Isaksson OGP 1982 Circumstantial evidence for a role of the secretory pattern of growth hormone in control of body growth. Acta Endocrinologica 99 24-30.

Jansson J-O, Ekberg S, Isaksson O, Mode A \& Gustafsson J-Å 1985 Imprinting of growth hormone secretion, body growth, and hepatic steroid metabolism by neonatal testosterone. Endocrinology 117 1881-1889

Kern PA, Ong JM, Goers JWF \& Pedersen ME 1988 Regulation of lipoprotein lipase immunoreactive mass in isolated human adipocytes. Journal of Clinical Investigation 81 398-406.

King GL \& Kahn CR 1980 Direct demonstration of separate receptors for growth and metabolic activities of insulin and multiplication stimulating activity (an insulin-like growth factor) using antibodies to the insulin receptors. Journal of Clinical Investigation 66 130-140.

Krauss RM, Windmueller HG, Levy RI \& Fredrickson DS 1973 Selective measurement of two different triglyceride lipase activities in rat postheparin plasma. Journal of Lipid Research 14 286-295.

Labarca C \& Paigen K 1980 A simple, rapid, and sensitive DNA assay procedure. Annals of Biochemistry 102 344-352.

Ladu MJ, Kapsas H \& Palmer WK 1991 Regulation of lipoprotein lipase in adipose and muscle tissues during fasting. American Journal of Physiology 260 R953-R959.

Leahy JL \& Vandekerkhove KM 1990 Insulin-like growth factor I at physiological concentrations is a potent inhibitor of insulin secretion. Endocrinology 126 1593-1598.

Levak-Frank S, Radner H, Walsh A, Stollberger R, Knipping G, Hoefler G, Sattler W, Weinstock PH, Breslow JL \& Zechner R 1995 Muscle-specific overexpression of lipoprotein lipase causes a severe myopathy characterised by proliferation of mitochondria and peroxisomes in transgenic mice. Journal of Clinical Investigation 96 976-986.

Linder C, Chernick SS, Fleck TR \& Scow RO 1976 Lipoprotein lipase and uptake of chylomicron triglyceride by skeletal muscle of rats. American Journal of Physiology 231 860-864.

Lithell H \& Boberg J 1978 Determination of lipoprotein-lipase activity in human skeletal tissues. Biochimica et Biophysica Acta 528 58-68. 
Murase T, Yamada N \& Ohsawa N 1980 Decline in postheparin plasma lipoprotein lipase in acromegalic patients. Metabolism 29 666-672.

Murase T, Yamada N \& Matsuzaki F 1981 The in vitro effect of growth hormone on adipose tissue lipoprotein lipase in the rat. Life Sciences 28 199-201.

Nilsson-Ehle P \& Schotz M 1976 A stable, radioactive substrate emulsion for assay of lipoprotein lipase. Journal of Lipid Research 17 $536-541$.

Nilsson-Ehle P \& Ekman R 1977 Rapid, simple and specific assays for lipoprotein lipase and hepatic lipase. Artery 3 194-209.

Ong JM, Kirchgessner TG, Schotz MC \& Kern PA 1988 Insulin increases the synthetic rate and messenger RNA levels of lipoprotein lipase in isolated rat adipocytes. Journal of Biological Chemistry 263 12933-12938.

Oscarsson J, Olofsson S-O, Vikman K \& Edén S 1991 Growth hormone regulation of serum lipoproteins in the rat: different growth hormone regulatory principles for apolipoprotein (apo) B and the sexually dimorphic apo E concentrations. Metabolism $\mathbf{1 1}$ 191-198.

Oscarsson J, Ottosson M, Wiklund O, Mårin P, Vikman-Adolfsson K, Björntorp P \& Edén S 1994 Low dose continuously infused growth hormone results in increased lipoprotein(a) and decreased low density lipoprotein cholesterol concentrations in middle-aged men. Clinical Endocrinology 41 109-116.

Oscarsson J, Ottosson M, Johansson J-O, Wiklund $\mathrm{O}$, Mårin $\mathrm{P}$, Björntorp P \& Bengtsson B-Å 1996 Two weeks of daily injections and continuous infusion of recombinant human growth hormone $(\mathrm{GH})$ in $\mathrm{GH}$-deficient adults. II. Effects on serum lipoproteins and lipoprotein and hepatic lipase activity. Metabolism 45 370-377.

Ottosson M, Vikman-Adolfsson K, Enerbäck S, Elander A, Björntorp P \& Edén S 1995 Growth hormone inhibits lipoprotein lipase activity in human adipose tissue. Journal of Clinical Endocrinology and Metabolism 80 936-941.

Peterson J, Olivecrona T \& Olivecrona-Bengtsson G 1985 Distribution of lipoprotein lipase and hepatic lipase between plasma and tissues: effects of hypertriglyceridemia. Biochimica et Biophysica Acta 837 262-270.

Quaife CJ, Mathews LS, Pinkert CA, Hammer R, Brinster RL \& Palmiter RD 1989 Histopathology associated with elevated levels of growth hormone and insulin-like growth factor I in transgenic mice. Endocrinology 124 40-48.

Randle PJ, Garland PB, Hales CN \& Newsholme EA 1963 The glucose fatty acid-cycle. Its role in insulin sensitivity and the metabolic disturbances of diabetes mellitus. Lancet 1 785-794.

Roberts TJ, Azain MJ, Hausman GJ \& Martin RJ 1992 Interaction of insulin and somatotropin on body weight gain, feed intake, and body composition in rat. American Journal of Physiology 267 E293-E299.

Samuelsson L, Strömberg K, Vikman K, Bjursell G \& Enerbäck S 1991 The CCAAT/enhancer binding protein and its role in adipocyte differentiation: evidence for direct involvement in terminal adipocyte development. EMBO Journal $103787-3793$.

Sieradzki J, Fleck H, Chatterjee AK \& Schatz H 1988 Stimulatory effect of insulin-like growth factor-I on ${ }^{3} \mathrm{H}$-thymidine incorporation, DNA content and insulin biosynthesis and secretion of isolated pancreatic rat islets. Journal of Endocrinology 177 59-62.

Sjöberg A, Oscarsson J, Olofsson S-O \& Edén S 1994 Insulin-like growth factor-I and growth hormone have different effects on serum lipoproteins and secretion of lipoproteins from cultured rat hepatocytes. Endocrinology 135 1415-1421.

Smith U, Sjöström L \& Björntorp P 1972 Comparison of two methods of determining human adipose cell size. Journal of Lipid Research 13 $822-824$

Spooner PM, Garrison MM \& Scow RO 1977 Regulation of mammary and adipose tissue lipoprotein lipase and blood triacylglycerol in rats during late pregnancy. Journal of Clinical Investigation 60 702-708.

Spooner PM, Chernick SS, Garrison MM \& Scow RO 1979 Insulin regulation of lipoprotein lipase activity and release in 3T3-L1 adipocytes. Journal of Biological Chemistry 245 10021-10029.

Tamura K, Kobayshi M, Ishii Y, Tamura T, Hashimoto K, Nakumara S, Niwa M \& Zapf J 1989 Primary structure of rat insulin-like growth factor-I and its biological activities. Journal of Biological Chemistry 264 5616-5621.

Tan MH, Sata T \& Havel RJ 1977 The significance of lipoprotein lipase in rat skeletal muscles. Journal of Lipid Research $\mathbf{1 8}$ 363-370.

Thissen J-P, Ketelslegers J-M \& Underwood LE 1994 Nutritional regulation of the insulin-like growth factors. Endocrine Reviews $\mathbf{1 5}$ 80-101.

Thorngren KG \& Hansson LI 1973 Effects of thyroxine on longitudinal bone growth in the hypophysectomized rat. Acta Endocrinologica 74 24-40.

Tomas FM, Knowles SE, Owens PC, Chandler CS, Francis GL \& Ballard FJ 1993 Insulin-like growth factor-I and more potent variants restore growth of diabetic rats without inducing all characteristic insulin effects. Biochemical Journal 291 781-786.

Vikman K, Isgaard J \& Edén S 1991 Growth hormone regulation of insulin-like growth factor-I mRNA in rat adipose tissue and isolated rat adipocytes. Journal of Endocrinology 31 139-145.

Vikman-Adolfsson K, Oscarsson J, Nilsson-Ehle P \& Edén S 1994 Growth hormone but not gonadal steroids influences lipoprotein lipase and hepatic lipase activity in hypophysectomized rats. Journal of Endocrinology 140 203-209.

Received 26 September 1997

Revised manuscript received 20 April 1998

Final version received 18 September 1998 Accepted 30 September 1998 